Original Research Paper

\title{
Aktivitas Antibakteri Ekstrak Metanol Batang Bidara Laut (Strychnos ligustrina) Terhadap Bakteri Patogen
}

\author{
Edy Kurniawan ${ }^{1}$, Dwi Soelistya Dyah Jekti ${ }^{1,2}$, Lalu Zulkifli ${ }^{1,2, *}$ \\ ${ }_{2}^{1}$ Program Studi Magister Pendidikan IPA, Program Pascasarjana Universitas Mataram, Mataram, Indonesia, 83125 \\ ${ }^{2}$ Program Studi Pendidikan Biologi PMIPA FKIP Universitas Mataram,Mataram,Indonesia, 83125.
}

\section{Article history}

Received: 31 Januari 2019

Revised: 12 Februari 2019

Accepted: 20 Februari 2019

Published: 28 Februari 2018

*Corresponding Author:

Lalu Zulkifli,

Program Studi Pendidikan

Biologi PMIPA FKIP

Universitas Mataram,

Mataram,Indonesia, 83125.

Email:lalu_zulkifli@unram.ac.id
Abstract : Strychnos ligustrina stem has been empirically used by the people of West Nusa Tenggara and Bali in the treatment of malaria, tooth ache and diarrhea, but there is no scientific data that supports it. This study aims to determine and prove the antibacterial activity of Strychnos ligustrina methanol extract to pathogenic bacteria in vitro and in vivo. This research is an experimental study conducted by measuring the inhibition zone $(\mathrm{mm})$ growth of pathogenic bacteria, determining minimum inhibitory concentration (MIC) and minimum killing concentration (MKC) in vitro, and determining the percentage of antibacterial activity of methanol extract of $S$. ligustrina stem in vivo. The experiment was conducted using 4 groups of concentrations of S. ligustrina stem methanol extract in an in vitro study of $25,50,75$, and $100 \%$ with ciprofloxacin as a positive control and aquadest as a negative control. In vivo studies experiments were carried out using 6 treatment groups of test animals male mice Balb / c (Mus musculus). The in vitro test results showed that methanol extract of S. ligustrina stems was able to inhibit the growth of pathogenic bacteria with medium categories of clinical isolates of Staphylococcus aureus and categories of weaks to Klebsiella pneumonia and Escherichia coli isolates. The minimum inhibitory concentration (MIC) for S. aureus and K. pneumonia bacteria isolates was at a concentration of $25 \%$ while for $E$. coli isolates at a concentration of $30 \%$. The methanol extract of the S. ligustrina stem has no killing power against the pathogenic bacteria tested. Antibacterial activity in vivo was able to inhibit the growth of S. aureus pathogenic bacteria by $6.60 \%$ (at $25 \%$ concentration), $8.62 \%$ (at $50 \%$ concentration), and $17.31 \%$ (at $100 \%$ concentration), against K. pneumonia was $11.85 \%$ (at $25 \%$ concentration), $51.21 \%$ (at $50 \%$ concentration), and $65.92 \%$ (at $100 \%$ concentration), against E. coliat 19.18\% (at concentration 25\%), 29.98\% (at 50\% concentration), and $40.88 \%$ (at $100 \%$ concentration). Methanol extract of $S$. ligustrina stem proved to have antibacterial activity in vitro and in vivo.

Key words: Srychnos ligustrina, pathogenic bacteria, antibacterial, in vitro, in Vivo.

Abstrak : Strychnos ligustrina secara empiris telah digunakan oleh masyarakat Nusa Tenggara Barat dan Bali dalam pengobatan penyakit malaria, sakit gigi, dan diare, tetapi belum ada data ilmiah yang mendukung. Penelitian ini bertujuan untuk menentukan dan membuktikan aktivitas antibakteri ekstrak metanol batang bidara laut terhadap bakteri patogen secara in vitrodan in vivo. Penelitian ini merupakan penelitian eksperimental yang dilakukan dengan mengukur zona hambat $(\mathrm{mm})$ pertumbuhan bakteri patogen, menentukan konsentrasi hambat minimum (KHM) dan konsentrasi bunuh minimum $(\mathrm{KBM})$ secara in vitro, serta menentukan persentase aktivitas antibakteri ekstrak metanol batang bidara laut secara in vivo. Percobaan dilakukan menggunakan 4 kelompok konsentrasi ekstrak metanol 
batang bidara laut pada penelitian in vitro yaitu $25,50,75$, dan $100 \%$ dengan ciprofloxacin sebagai kontrol positif serta aquadest sebagai kontrol negatif. Pada penelitian in vivo percobaan dilakukan menggunakan 6 kelompok perlakuan hewan uji mencit jantan galur Balb/c (Mus musculus). Hasil uji in vitro menunjukkan ekstrak metanol batang bidara laut mampu menghambat pertumbuhan bakteri patogen dengan kategori sedang terhadap Staphylococcus aureus isolat klinis dan kategori lemah terhadap Klebsiella pneumonia dan Escherichia coli isolat klinis. Nilai konsentrasi hambat minimum (KHM) untuk isolat bakteri $S$. aureus dan K. pneumoniae adalah pada konsentrasi $25 \%$ sedangkan untuk isolat E. coli pada konsentrasi $30 \%$. Ekstrak metanol batang bidara laut tidak memiliki daya bunuh terhadap bakteri patogen yang diuji. Aktivitas antibakteri secara in vivo mampu menghambat pertumbuhan bakteri patogen $S$. aureus sebesar 6,60\% (pada konsentrasi 25\%), 8,62\% (pada konsentrasi 50\%), dan 17,31\% (pada konsentrasi $100 \%$ ), terhadap $K$. pneumonia sebesar $11,85 \%$ (pada konsentrasi 25\%), 51,21\% (pada konsentrasi 50\%), dan 65,92\% (pada konsentrasi $100 \%$ ), terhadap E. coli sebesar $19,18 \%$ (pada konsentrasi $25 \%$ ), 29,98\% (pada konsentrasi 50\%), dan 40,88\% (pada konsentrasi $100 \%$ ). Ekstrak metanol batang bidara laut terbukti memiliki aktivitas antibakteri secara in vitro dan in vivo.

Kata kunci: Srychnos ligustrina, bakteri patogen, antibakteri, in vitro, in vivo

\section{Pendahuluan}

Bakteri merupakan mikroorganisme prokariotik yang dapat memberikan dampak positif bagi kesehatan sebagai flora normal, tetapi dapat juga memberikan dampak negatif dengan menimbulkan penyakit atau bersifat patogen (Kumar dan Chordia, 2017). Pengendalian dan penanganan penyakit yang disebabkan oleh bakteri dapat dilakukan melalui pengobatan. Obat yang banyak digunakan untuk menghambat/membunuh bakteri patogen yang menginfeksi manusia sebagian besar berupa antibiotik sintetik yang memiliki risiko resisten sehingga menyebabkan gagalnya pengobatan dan pasien menjadi terinfeksi dalam waktu yang lama(Utami, 2011). Jika dilihat dari risiko terjadinya resistensi antibiotik sintetik terhadap bakteri patogen, maka dibutuhkan solusi untuk mencari obat alternatif yang aman, murah, mudah diperoleh dan lebih baik sebagai obat baru pengganti antibiotik sintetik. Senyawa bahan antibakteri tersebut dapat diperoleh dari mikroba, tumbuh-tumbuhan dan hewan. Peluang mendapatkan bahan antibakteri alami di Indonesia sangat besar, mengingat Indonesia merupakan negara yang kaya akankeanekaragaman hayati (Setiawan et al., 2014).
Metabolit sekunder yang dihasilkan oleh tumbuhan memiliki potensi sebagai obat herbal, antioksidan, zat pewarna, dan penambah aroma pada makanan (Febjislami S, 2017). Metabolit sekunder pada tumbuhan juga memainkan peranan penting dalam menentukan aktivitas biologis obat tradisional yang telah digunakan (Solikhah, 2016). Setiawan et al., (2014) menerangkan bahwa tumbuhan sebagai sumber bahan obat yang cukup dikenal di wilayah Nusa Tenggara Barat (NTB) dan Bali adalah Bidara laut (Strychnos ligustrina). Tumbuhan Bidara laut di wilayah NTB (Bima \& Dompu) memiliki nama lokal/daerah Songga, sedangkan di wilayah Bali disebut dengan Kayu pait. Masyarakat Dompu NTB sering menggunakan bagian batang dan biji tumbuhan Bidara laut untuk pengobatan. Kulit batang bidara laut digunakan untuk mengobati sakit gigi, obat luka dan malaria, biji untuk mengobati malaria, diare dan pegal linu, akar untuk mengobati sakit perut/diare.

Batang bidara laut telah dibuat dalam bentuk produk gelas yang dapat langsung dimanfaatkan dengan caramemasukkan air panas ke dalam gelas kayu tersebut. Masyarakat meyakini bahwa batang bidara laut berkhasiat untuk mengobati berbagai macam penyakit (Setiawan et al., 2014). Keyakinan masyarakat tentang khasiat bidara laut diperkuat oleh beberapa penelitian 
terdahulu diantaranya oleh Sumiati (2014) yaitu ekstrak kloroform dan etanol biji bidara laut memiliki aktivitas antibakteri terhadap S. aureus dan Salmonella thypi secara in vitro. Strychnos lucida/ligustrina telah dilaporkan sebagai agen antibakteri, antikanker, dan antioksidan, hasil penelitian ini menguatkan secara ilmiah penggunaan tumbuhan bidara laut sebagai obat tradisional oleh masyarakat (Sarmento et al., 2015). Perlu dibuktikan khasiat ekstrak metanol batang bidara laut secara ilmiah. Tujuan penelitian ini adalah untuk menentukan dan membuktikan aktivitas antibakteri ekstrak metanol batang bidara laut terhadap bakteri patogen secara in vitro dan in vivo.

\section{Bahan dan Metode}

\section{Pembuatan Ekstrak}

Ekstrak batang bidara laut dibuat dengan metode maserasi. Batang bidara laut dipotong kecilkecil kemudian dikeringanginkan. Potongan batang yang sudah kering selanjutnya dihaluskan menjadi serbuk menggunakan blender. Serbuk simplisia dimaserasi dengan cara direndam dengan pelarut metanol 95\% sampai terendam seluruhnya dengan perbandingan antara simplisia dan pelarut adalah 1:4 selama 24 jam (Zuhrotun et al., 2009), 500 gr simplisia dilarutkan dengan 2 liter pelarut metanol 95\%, kemudian dilakukan penyaringan menggunakan kertas saring. Residu kembali dimaserasi dengan cara yang sama sampai pelarut berwarna bening. Ekstrak hasil maserasi ditampung menjadi satu dan diuapkan untuk memisahkan pelarutnya. Penguapan dilakukan menggunakan alat rotary evaporator sampai pelarut habis menguap, dan diperoleh ekstrak pekat dalam bentuk pasta.

\section{Uji In Vitro}

Uji aktivitas antibakteri dilakukan dengan menggunakan tiga isolat bakteri patogen yang digunakan berdasarkan Amrullah et al., (2018) yaitu Staphylococcus aureus, Klebsiella pneumonia, dan Escherichia coli secara aseptik dengan metode difusi sumuran. Masing-masing suspensi bakteri uji diusapkan/spread secara merata pada media MHA dengan menggunakan swab kapas steril, kemudian didiamkan selama beberapa menit agar suspensi bakteri meresap pada media. Pembuatan sumuran dilakukan dengan cara membuat empat lubang berdiameter $6 \mathrm{~mm}$ pada media MHA yang telah diinokulasikan dengan bakteri uji, ke dalam lubang sumuran diinjeksikan ekstrak yang akan diuji dengan menggunakan mikropipet steril. Volume ekstrak uji dari tiap-tiap konsentrasi yang dinjeksikan ke dalam lubang sumuran adalah sebanyak $50 \mu \mathrm{L}$, selanjutnya olesan bakteri yang telah diinjeksikan tiap konsentrasi bahan uji diinkubasi pada temperatur $37^{\circ} \mathrm{C}$ selama 24 jam suasana aerob.

Jika terdapat aktivitas antibakteri, maka di sekitar lubang sumuran akan terlihat terbentuknya zona jernih yaitu daerah yang tidak ditumbuhi bakteri yang mengindikasikan terhambatnya pertumbuhan bakteri uji. Kategori zona hambat seperti pada Tabel 1.

Tabel 1. Kategori Zona Hambat Aktivitas Antibakteri Ekstrak Metanol Batang Bidara laut

\begin{tabular}{ccc}
\hline No. & Diameter $(\mathbf{m m})$ & Kategori \\
\hline 1 & Diameter $>12 \mathrm{~mm}$ & Kuat $(+++)$ \\
2 & Diameter $9<\mathbf{D} \leq 12 \mathrm{~mm}$ & Sedang $(++)$ \\
3 & Diameter $7<\mathbf{D} \leq 9 \mathrm{~mm}$ & Lemah $(+)$ \\
4 & Diameter $=6 \mathrm{~mm}$ & Tidak ada \\
& & hambatan $(-)$ \\
\hline
\end{tabular}

Sumber: Pan et al., (2009)

\section{Penentuan Konsentrasi Hambat Minimum dan Konsentrasi Bunuh Minimum}

Penentuan KHM dilakukan berdasarkan nilai kerapatan optik/Optical Density (OD) dari suspensi tiap-tiap bakteri uji dengan metode serial dilusi yaitu membandingkan turbiditas/kekeruhan awal dan akhir suspensi uji. Penentuan KBM ditandai dengan ada tidaknya pertumbuhan bakteri pada media biakan (Nutrient Agar).

\section{Pembuatan Suspensi Bakteri Uji}

Bakteri uji (S. aureus, K. pneumonia, E. coli) masing-masing diambil dengan jarum ose dan disuspensikan dengan cara dimasukkan ke dalam tabung berisi masing-masing $5 \mathrm{ml}$ larutan $\mathrm{NaCl}$ fisiologis steril $0,9 \%$. Suspensi yang terbentuk disetarakan dengan standar McFarland No. 0,5 yaitu $1,5 \times 10^{8} \mathrm{CFU} / \mathrm{ml}$. 


\section{Uji In Vivo}

Hewan uji yang digunakan yaitu mencit jantan berumur 2-3 bulan, dikelompokkan dalam 6 kelompok untuk masing-masing bakteri, masingmasing kelompok terdiri dari 5 ekor mencit dan diaklimatisasikan selama 14 hari untuk penyesuaian dengan lingkungan. Kelompok 1 merupakan kelompok yang tidak diinfeksi/Blanko, kemudian kelompok 2,3,4,5, dan 6 merupakan kelompok yang diinfeksikan dengan $0,5 \mathrm{ml}$ suspensi bakteri uji secara intraperitoneal (Rosenova et al., 2014). Kelompok 1 sebagai kontrol normal, kelompok 2 sebagai kontrol negatif hanya diberikan $0,5 \mathrm{ml}$ aquades steril, kelompok 3 merupakan kelompok kontrol positif mendapatkan pengobatan dengan antibiotik ciprofloksasin dengan dosis $2 \mathrm{mg} / 20$ gr berat badan mencit (CLSI, 2016) dan kelompok 4, 5, 6 merupakan kelompok perlakuan yang mendapatkan pengobatan dengan ekstrak metanol batang bidara laut dengan dosis bertururt-turut 25 , 50, dan 100\% (Rotty et al., 2015).

Pemberian obat (antibiotik dan ekstrak batang bidara laut) dilakukan secara oral 1 kali sehari sebanyak $0,5 \mathrm{ml}$ selama 3 hari berturut-turut. Pada hari ke 4 dilakukan pengambilan cairan intraperitoneal mencit dengan menggunakan micro spuit sebanyak 100 ul, selanjutnya cairan dikultur pada media Nutrient Agar menggunakan metode spread plate dan diinkubasi pada $37^{\circ} \mathrm{C}$ selama 24 jam dalam suasana aerob. Koloni yang tumbuh (bakteri yang diinokulasi ke dalam cairan intraperitoneal, karena dalam keadaan normal cairan intraperitoneal steril dari bakteri flora normal) dihitung dengan alat colony counter (Rosenova et al., 2014).Data hasil perhitungan dengan metode plate count digunakan untuk menentukan persentase aktivitas antibakteri ekstrak metanol batang bidara laut terhadap bakteri uji.

Persentase aktivitas antibakteri diperoleh dengan menggunakan rumus perhitungan (Rotty et al., 2015):

$$
\frac{R L K N-R L K}{R L K N}
$$

Keterangan :

$$
\text { RLKN = Rataan Logaritma Kontrol Negatif }
$$

RLK = Rataan Logaritma Kelompok yang akan dihitung

\section{Analisis Data}

Data daya hambat dan persentase aktivitas antibakteri ekstrak metanol batang bidara laut secara in vitro atau in vivo jika berdistribusi normal dan homogen diuji dengan One Way ANOVA dan jika berdistribusi tidak normal diuji dengan Kruskal Wallis Test pada taraf kepercayaan 95\%. Analisis data pada hasil uji in vitro dilakukan dengan metode Kruskal Wallis Test karena data berdistribusi tidak normal dan tidak homogen. Hasil uji Kruskal Wallis terhadap ketiga bakteri uji menunjukkan nilai probabilitas $(\mathrm{p}<0,05)$, artinya ekstrak metanol batang bidara laut memberikan pengaruh nyata/signifikan terhadap penghambatan pertumbuhan bakteri patogen isolat klinis secara in vitro.

Analisis data hasil uji in vivo dilakukan dengan metode One Way Anova pada bakteri uji $S$. aureus dan $K$. pneumonia sedangkan pada bakteri uji E. coli menggunakan metode Kruskal Wallis Test. Hasil uji One Way Anova diperoleh nilai signifikansi sebesar $0,000 \quad(p<0,05)$ yang menunjukkan terdapat perbedaan yang bermakna pada pertumbuhan jumlah koloni kontrol negatif dan jumlah koloni kelompok perlakuan ekstrak metanol batang bidara laut serta kontrol positif. Hasil uji Kruskal Wallis pada bakteri uji E. coli diperoleh nilai probabilitas $(\mathrm{p}<0,05)$ artinya ekstrak metanol batang bidara laut memberikan pengaruh nyata/signifikan terhadap penghambatan pertumbuhan bakteri $E$. coli isolat klinis secara in vivo.

\section{Hasil dan Pembahasan}

Ekstrak metanol batang bidara laut pada tabel 2, dalam konsentrasi 25, 50, 75, dan $100 \%$ mampu menghambat pertumbuhan bakteri $S$. aureus isolat klinis dengan kategori sedang serta terjadi peningkatan besar daya hambat bakteri seiring dengan besarnya konsentrasi ekstrak. Ekstrak metanol batang bidara laut dalam konsentrasi 25, 50, 75, dan 100\% mampu menghambat pertumbuhan bakteri $K$. pneumoniae isolat klinis dengan diameter hambatan kategori lemah, tetapi terjadi peningkatan besar daya hambat 
bakteri seiring dengan besarnya konsentrasi ekstrak. Ekstrak metanol batang bidara laut dalam konsentrasi 50, 75, dan 100\% mampu menghambat pertumbuhan bakteri Escherichia coli isolat klinis dengan kategori sedang dan lemah serta terjadi peningkatan besar daya hambat bakteri seiring dengan besarnya konsentrasi ekstrak.

Tabel 2. Hasil Pengukuran Zona Hambat Bakteri Uji dengan Perlakuan Ekstrak Metanol Batang Bidara Laut (Strychnos ligustrina) pada berbagai konsentrasi

\begin{tabular}{|c|c|c|c|c|c|c|}
\hline \multirow{3}{*}{ Jenis Bakteri } & \multicolumn{4}{|c|}{ Zona Hambat $(\mathrm{mm})$} & \multirow{2}{*}{\multicolumn{2}{|c|}{ Kontrol }} \\
\hline & \multicolumn{4}{|c|}{ Konsentrasi Ekstrak Metanol (\%) } & & \\
\hline & $25 \%$ & $50 \%$ & $75 \%$ & $100 \%$ & $\mathrm{~K}+$ & $\mathrm{K}-$ \\
\hline $\begin{array}{l}\text { Staphylococcus } \\
\text { aureus }\end{array}$ & 9,83 & 10,83 & 11,33 & 11,50 & 32,83 & 0 \\
\hline Kategori & S & S & S & $S$ & K & \\
\hline Standar Deviasi & 0,41 & 0,41 & 0,52 & 0,55 & 0,41 & 0 \\
\hline $\begin{array}{l}\text { Klebsiella } \\
\text { pneumonia }\end{array}$ & 7,67 & 8,17 & 8,17 & 9 & 30 & 0 \\
\hline Kategori & $\mathrm{L}$ & $\mathrm{L}$ & $\mathrm{L}$ & $\mathrm{L}$ & K & \\
\hline Standar Deviasi & 0,52 & 0,41 & 0,41 & 0,63 & 0,63 & 0 \\
\hline Escherichia coli & 0 & 9 & 10 & 10 & 37 & 0 \\
\hline Kategori & & $\mathrm{L}$ & $S$ & S & $\mathrm{K}$ & \\
\hline Standar Deviasi & 0 & 0,41 & 0,55 & 0,41 & 0,84 & 0 \\
\hline
\end{tabular}

Keterangan: $\mathrm{K}=$ Kuat; $\mathrm{S}=$ Sedang; $\mathrm{L}=$ Lemah; $0=$ tidak ada daya hambat

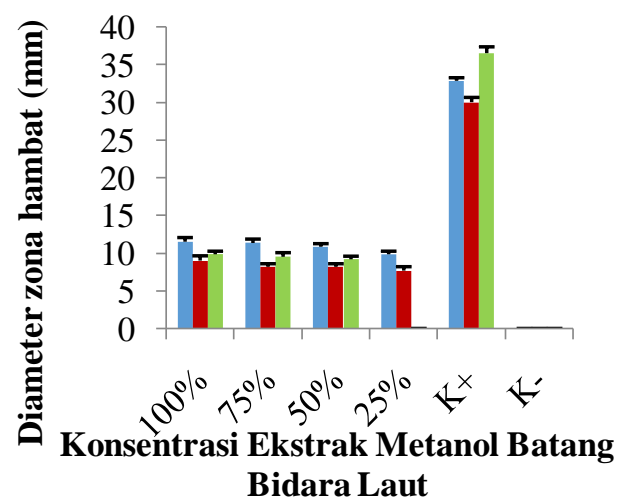

Gambar 1. Grafik zona hambat terhadap bakteri uji Staphylococcus aureus (1), Klebsiella pneumonia । ) dan Escherichia coli ( $)$

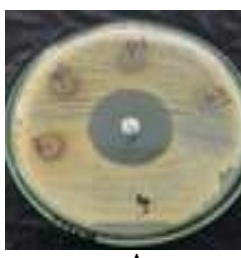

A

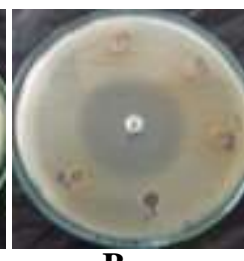

B

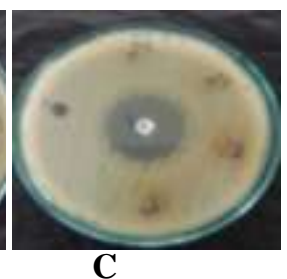

Gambar 2. Aktivitas antibakteri ekstrak metanol batang bidara laut metode sumuran. Zona di tengah medium adalah kontrol positif(cyprofloxacin); A:

Staphylococcusaureus, B: Klebsiellapneumonia, dan C: Escherichia coli.

Tabel 3. Hasil Uji Konsentrasi Hambat Minimum (KHM) Ekstrak Metanol Batang Bidara Laut (Strychnos ligustrina) terhadap Bakteri Uji

\begin{tabular}{|c|c|c|c|c|c|c|}
\hline \multirow{3}{*}{$\begin{array}{l}\text { Perlakuan } \\
\text { Ekstrak } \\
\text { Metanol } \\
(\%)\end{array}$} & \multicolumn{6}{|c|}{$\begin{array}{l}\text { Selisih Nilai Absorbansi (OD) Bakteri Uji dengan Panjang Gelombang } \\
560 \mathrm{~nm}\end{array}$} \\
\hline & \multicolumn{2}{|c|}{ Staphylococcus aureus } & \multicolumn{2}{|c|}{ Klebsiella pneumonia } & \multicolumn{2}{|c|}{ Escherichia coli } \\
\hline & $\begin{array}{l}\text { Selisih } \\
\text { OD }\end{array}$ & $\begin{array}{l}\text { Keterangan } \\
\text { Daya } \\
\text { Hambat }\end{array}$ & $\begin{array}{l}\text { Selisih } \\
\text { OD }\end{array}$ & $\begin{array}{l}\text { Keterangan } \\
\text { Daya } \\
\text { Hambat }\end{array}$ & $\begin{array}{l}\text { Selisih } \\
\text { OD }\end{array}$ & $\begin{array}{l}\text { Keterangan } \\
\text { Daya } \\
\text { Hambat }\end{array}$ \\
\hline 40 & 0,1 & + & 0,1 & + & 0,1 & + \\
\hline 30 & 0,08 & + & 0,1 & + & 0,1 & + \\
\hline 25 & 0,03 & + & 0,03 & + & 0,65 & - \\
\hline 20 & 0,6 & - & 0,61 & - & td & $\operatorname{td}$ \\
\hline $\mathrm{K}+$ & 0,01 & + & 0,01 & + & $\begin{array}{c}0,01 \\
5\end{array}$ & + \\
\hline K- & 0,6 & - & 0,6 & - & 0,61 & - \\
\hline Keteran & lai O & $\begin{array}{l}\text { lapat akti } \\
\text { bakteri; }\end{array}$ & $\begin{array}{l}\text { is pel } \\
=\end{array}$ & lambata & $\begin{array}{l}\text { ertum } \\
\text { it ak }\end{array}$ & $\begin{array}{l}\text { han } \\
\text { itas } \\
\text { lisih }\end{array}$ \\
\hline
\end{tabular}

Tabel 4. Hasil Uji Konsentrasi Bunuh Minimum (KBM) Ekstrak Metanol Batang Bidara Laut (Strychnos ligustrina) terhadap Bakteri Uji

\begin{tabular}{|c|c|c|c|c|c|c|c|c|c|}
\hline \multirow{2}{*}{ Bakteri } & \multicolumn{9}{|c|}{ Konsentrasi (\%) } \\
\hline & 20 & 25 & 30 & 40 & 50 & 60 & 70 & $\mathrm{~K}-$ & $\mathrm{K}+$ \\
\hline $\begin{array}{l}\text { Staphylococcusau } \\
\text { reus }\end{array}$ & + & + & + & + & + & + & + & + & - \\
\hline $\begin{array}{l}\text { Klebsiella } \\
\text { pneumonia }\end{array}$ & + & + & + & + & + & + & + & + & + \\
\hline Escherichia coli & + & + & + & + & + & + & + & + & + \\
\hline
\end{tabular}

Keterangan: $+\quad=$ Tumbuh; $-=$ Tidak tumbuh; $\mathrm{K}+=$ Kontrol Positif (Ciprofloxacin); K-= Kontrol Negatif (Media Nutrient Broth) 
Tabel 5. Data hasil uji in vivo

\begin{tabular}{lllll}
\hline \multirow{5}{*}{ Jenis Bakteri } & $\begin{array}{l}\text { Perlaku } \\
\text { an } \\
\text { (dosis) }\end{array}$ & $\begin{array}{l}\text { Rata-rata } \\
\text { Pertumbuh } \\
\text { an Koloni } \\
\text { (CFU/50u } \\
\text { L) }\end{array}$ & $\begin{array}{l}\text { Rata-rata } \\
\text { pogaritma } \\
\text { an koloni }\end{array}$ & $\begin{array}{l}\text { Persenta } \\
\text { se } \\
\text { aktivitas } \\
\text { antibakt } \\
\text { eri }\end{array}$ \\
\hline Staphylococ & P1 & 0 & 0 & - \\
cus aureus & P2 & $2,09 \times 10^{2}$ & 2,3205 & - \\
& P3 & $0,21 \times 10^{2}$ & 1,3188 & $43,16 \%$ \\
& P4 & $1,47 \times 10^{2}$ & 2,1672 & $6,60 \%$ \\
& P5 & $1,32 \times 10^{2}$ & 2,1205 & $8,62 \%$ \\
& P6 & $0,83 \times 10^{2}$ & 1,9189 & $17,31 \%$ \\
\hline Klebsiella & P1 & 0 & 0 & - \\
pneumonia & P2 & $1,92 \times 10^{2}$ & 2,2833 & - \\
& P3 & $0,04 \times 10^{2}$ & 0,6020 & $73,63 \%$ \\
& P4 & $1,03 \times 10^{2}$ & 2,0128 & $11,85 \%$ \\
& P5 & $0,13 \times 10^{2}$ & 1,1139 & $51,21 \%$ \\
& P6 & $0,06 \times 10^{2}$ & 0,7781 & $65,92 \%$ \\
\hline Escherichia & P1 & 0 & 0 & - \\
& P2 & $2,00 \times 10^{2}$ & 2,3010 & - \\
& P3 & $0,07 \times 10^{2}$ & 0,8517 & 62,98 \\
& P4 & $0,72 \times 10^{2}$ & 1,8596 & 19,18 \\
& P5 & $0,41 \times 10^{2}$ & 1,6111 & 29,98 \\
& P6 & $0,23 \times 10^{2}$ & 1,3602 & 40,88 \\
\hline Keterangan: & P1 & &
\end{tabular}

Keterangan: $\mathrm{P} 1=$ kontrol normal $($ Blanko)/ tanpa perlakuan; $\mathrm{P} 2=$ kontrol negatif; $\mathrm{P} 3=$ kontrol positif; $\mathrm{P} 4=$ perlakuan pemberian ekstrak 25\%; P5= perlakuan pemberian ekstrak 50\%; P6= perlakuan pemberian ekstrak $100 \%$; $0=$ tidak ada pertumbuhan koloni; - = tidak ada aktivitas antibakteri

Data tabel 2 dan gambar 1 menunjukkan bahwa ekstrak metanol batang bidara laut dalam konsentrasi 25, 50, 75, dan $100 \%$ mampu menghambat pertumbuhan bakteri patogenisolat klinis dengan kategori lemah hingga sedang serta terjadi peningkatan besar daya hambat bakteri seiring dengan besarnya konsentrasi ekstrak, peningkatan tersebut sesuai dengan pendapat Pelczar dan Chan (2008) bahwa semakin tinggi konsentrasi suatu zat antibiotik maka semakin cepat mikroorganisme terbunuh dan terhambat pertumbuhannya.

Tabel 3 menunjukkan data konsentrasi hambat minimum (KHM) ekstrak metanol batang bidara laut terhadap bakteri patogen dengan KHM 25\% terhadap bakteri S. aureus dan K. pneumonia, serta KHM $30 \%$ terhadap E. coli. Data tabel 4 menunjukkan semua bakteri pada tiap-tiap konsentrasi tumbuh sebagai indikasi ekstrak metanol batang bidara laut tidak memiliki efek bunuh terhadap isolat klinis yang diuji.
Pada tabel 5 diperoleh data kelompok kontrol normal (P1) tidak terdapat pertumbuhan koloni bakteri patogen, menurut Madigan et al., (2003)dalam keadaan normal cairan intraperitoneum bersifat steril, oleh karena itu pada kelompok kontrol normal tidak terdapat pertumbuhan koloni bakteri karena kelompok ini tidak diberi infeksi bakteri. Data kontrol negatif (P2) pada tabel 5 menunjukkan pertumbuhan koloni bakteri yang paling banyak di semua jenis bakteri uji, sehingga persentase aktivitas antibakteri bernilai negatif atau tidak ada aktivitas antibakteri. Hal ini terjadi karena setelah 24 jam terinfeksi dan selama 3 hari berturut-turut kelompok kontrol negatif (P2) hanya diberikan aquadest steril yang tidak memiliki potensi sebagai antibakteri, sehingga bakteri yang disuntikkan pada hewan percobaan terus bertumbuh. Data kontrol positif ciprofloxacin (P3) pada tabel 5 menunjukkan nilai aktivitas antibakteri dengan penurunan pertumbuhan koloni bakteri uji sebesar $62,98 \%$ terhadap E. coli, $73,63 \%$ terhadap $K$. pneumonia, dan $43,16 \%$ terhadap $S$. aureus.

Kelompok perlakuan pada tabel 5 (P4, P5, P6) menunjukkan aktivitas antibakteri dengan penurunan pertumbuhan koloni terhadap bakteri $E$. coli sebesar P4=19,18\%; P5=29,98\%; P6= 40,88\%. Bakteri $K$. pneumonia dengan persentase aktivitas antibakteri sebesar P4=11,85\%; P5=51,21\%; dan P6 $=65,92 \%$. Persentase aktivitas antibakteri ekstrak metanol batang bidara laut terhadap $S$. aureus sebesar $\mathrm{P} 4=6,60 \%$; $\mathrm{P} 5=8,62 \%$; dan $\mathrm{P} 6=17,31 \%$.

Aktivitas antibakteri ekstrak metanol batang bidara laut secara in vitro dan in vivo pada ketiga bakteri uji menunjukkan hasil yang berbeda. Aktivitas antibakteri pada uji in vitro lebih baik pengaruhnya pada isolat bakteri $S$. aureus dengan diameter zona hambat berdasarkan Pan et al., (2009) kategori sedang (++) dibandingkan isolat bakteri $K$. pneumonia kategori lemah $(+)$ dan $E$. coli diameter zona hambat dengan kategori lemah (+) hingga sedang (++). Daya tahan bakteri Gram negatif secara in vitro lebih kuat karena memiliki struktur dinding sel yang lebih kompleks dari bakteri Gram positif, perbedaan utama adalah adanya lapisan membran luar yang meliputi peptidoglikan dan lapisan lipopolisakarida yang bersifat sebagai penghalang masuknya senyawa antibakteri/antibiotik ke dalam sel bakteri, sedangkan dinding sel bakteri Gram positif tidak 
memiliki lapisan lipopolisakarida sehingga senyawa antibiotik dapat masuk ke dalam sel dan menyebabkan sel mengalami lisis (Rahmawati et al., 2014). Struktur dinding sel bakteri Gram positif berlapis tunggal yang relatif lebih sederhana sehingga memudahkan senyawa antibakteri untuk masuk ke dalam sel dan menemukan sasaran untuk bekerja, sedangkan bakteri Gram negatif lebih resisten terhadap senyawa antibakteri karena struktur dinding sel bakteri Gram negatif terdiri dari tiga lapis dan lebih kompleks (Sepriana et al., 2017).

Hasil uji in vivo menunjukkan hal yang berbeda, persentase penurunan pertumbuhan koloni sebagai akibat dari aktivitas antibakteri pada $K$. pneumoniae dan $E$. coli lebih baik dari pada isolat $S$. aureus. Perbedaan pengaruh aktivitas antibakteri ekstrak metanol batang bidara laut secara in vitro dan in vivo diduga karena kemampuan $S$. aureus menghasilkan enzim koagulase, katalase dan banyak zat ekstra seluler seperti mikrokapsul polisakarida sehingga mampu menggumpalkan fibrinogen dalam plasma darah yang mengakibatkan bakteri terlindung dari fagositosis serta respon sistem imun dari inang (Madigan et al., 2003). Fakta yang tidak dapat dibantah bahwa pada metode in vivo dipengaruhi oleh faktor imunitas oleh karena itu penurunan jumlah koloni bakteri hasil uji invivo pada $S$. aureus lebih kecil dari pada penurunan jumlah koloni bakteri pada $K$. pneumoniae dan E. coli.

Ekstrak metanol batang bidara laut memiliki aktivitas antibakteri terhadap bakteri patogen (S. aureus $(\mathrm{Gram}+), K$. pneumonia dan $E$. coli (Gram -)) secara in vitro dan in vivo. Hasil penelitian ini sesuai dengan hasil penelitian pendahulu tentang aktivitas antibakteri ekstrak etanol dan kloroform biji bidara laut oleh Sumiati (2014) yaitu ekstrak kloroform dan etanol biji bidara laut memiliki aktivitas antibakteri terhadap S. aureus dan Salmonella thypi secara in vitro. Khasiat bidara laut sebagai tumbuhan obat juga diperkuat oleh penelitian terdahulu yang telah dilakukan oleh Wahjoedi dan Pudjiastuti (1993) menggunakan infusa batang bidara laut secara in vivo dengan kesimpulan hasil bahwa infusa batang bidara laut memberikan efek positif sebagai anti radang, anti nyeri, dan hipoglikemik tanpa mengganggu fungsi hati dan lambung hewan percobaan.
Strychnos lucida/ligustrina telah dilaporkan sebagai agen antibakteri, antikanker, dan antioksidan, hasil penelitian ini menguatkan secara ilmiah penggunaan tumbuhan bidara laut sebagai obat tradisional oleh masyarakat Timor (Sarmento et al., 2015). Ekstrak metanol batang bidara laut yang digunakan dalam penelitian ini dapat menjadi tambahan sumber referensi tentang pelarut lain selain pelarut-pelarut yang telah digunakan oleh penelitian terdahulu.

Aktivitas antibakteri yang dikandung dalam ekstrak metanol batang bidara laut diduga karena kandungan senyawa yang terdapat dalam ekstrak metanol batang bidara laut yaitu fenol, flavonoid, tannin dan alkaloid dengan senyawa turunannya strychnine (Setiawan et al., 2014). Alkaloid merupakan senyawa aktif dalam ekstrak metanol batang bidara laut yang berperan sebagai anti malaria, sedangkan fenol dan tanin merupakan senyawa aktif yang berperan sebagai antibakteri serta flavonoid sebagai antioksidan (Gusmailina dan Komarawati, 2015). Kandungan antioksidan yang dimiliki oleh bidara laut sangat berperan dalam meningkatkan imunitas tubuh hewan uji untuk melawan bakteri patogen (Werdhasari, 2014).

Mekanisme antibakteri senyawa tanin adalah membentuk senyawa kompleks dengan protein melalui ikatan hidrogen sehingga protein akan terdenaturasi dan metabolisme bakteri menjadi terganggu (Makkar et al., 1991). Senyawa antibakteri lain yang terkandung dalam ekstrak metanol batang bidara laut adalah fenol, fenol memiliki mekanisme antibakteri dengan meracuni protoplasma dan menembus dinding sel serta mengendapkan protein sel bakteri, selanjutnya fenol akan menginaktifkan enzim essensial di dalam sel bakteri yang menyebabkan kebocoran sel dan menghambat pertumbuhan bakteri (Juliantina et al., 2009). Peningkatan dosis ekstrak metanol batang bidara laut berbanding lurus dengan persentase aktivitas antibakteri. Fakta tersebut sesuai dengan pendapat Pelczar dan Chan (2008) bahwa semakin tinggi konsentrasi suatu zat antibiotik maka semakin cepat mikroorganisme terbunuh dan terhambat pertumbuhannya.

\section{Kesimpulan} Ekstrak metanol batang bidara laut
memiliki aktivitas antibakteri terhadap 
pertumbuhan bakteri patogen secara in vitro dengan kekuatan daya hambat kategori lemah hingga sedang dan dikuatkan dengan hasil uji in vivo diperoleh persentase aktivitas antibakteri dalam menghambat pertumbuhan bakteri patogen yang mendekati daya hambat kontrol positif antibiotik sehingga batang bidara laut potensial untuk dikembangkan sebagai obat herbal terstandarisasi.

\section{Ucapan Terima Kasih}

Penulis mengucapkan terima kasih kepada Kementerian Riset, Teknologi dan Pendidikan Tinggi atas dukungan dana beasiswa BPPDN tahun 2015, Magister Pendidikan IPA Pascasarjana Universitas Mataram dan Politeknik Medica Farma Husada Mataram atas bimbingan dan dukungan moril maupun materil.

\section{Daftar Pustaka}

Amrullah, L.W.Z., Jekti, D.S.D. \& Zulkifli, L (2018). Isolation and Molecular Identification of Endophytic bacteria from Red Betel Root (Piper crocatum Ruiz \& Pav) as a Producer of Anti-Bacterial Compounds. IOSR Journal of Biotechnology and Biochemistry, 4 (1): 2732. https://doi.org/10.9790/264X-04012732

Clinical \& Laboratory Standards Institute. (2016). Performance Standards for Antimicrobial Susceptibility Testing. $26^{\text {th }}$ Ed. Wayne, USA: CLSI Supplement M100S. ISBN 156238-923-8 [Print]; ISBN 1-56238-924-6 [Electronic].

Febjislami, S. (2017). Pusat Studi Agrikultur Sayuran Kita. Identifikasi Sumber dan Kegunaan Senyawa Metabolit Sekunder Tanaman Cola (Cola acuminata). (online) https://sayurankita.com/2017/09/13/.

Gusmailina \& Komarayati, S. (2015). Eksplorasi Potensi Senyawa Organik Kayu Ular (Strycnos lucida) sebagai Sumber Biofarmaka, Prossiding Seminar Nasional Masyarakat Biodiversitas Indonesia, 1 (7). https://doi.org/10.13057/psnmbi/m010738
Juliantina, D. A., Citra, B., Nirwani, T. Nurmasitoh, E. T. \& Bowo. (2009). Manfaat sirih merah (Piper crocatum) sebagai agen antibacterial terhadap Gram positif dan Gram negatif. Jurnal Kedokteran dan Kesehatan Indonesia I (1): 5. http://jurnal.uii.ac.id/JKKI.

Anil Kumar, A., \& Chordia, N. (2017). Role of Microbes in Human Health. Applied Microbiology:Open Access 3(2): 1-3. DOI: https://doi.org/10.4172/24719315.1000131.

Madigan Michael T., Martinko, J.M., \& Parker, J. (2003). Brock Biology of Microorganism, $10^{\text {th }}$ ed. USA: Pearson Education, Inc. ISBN: 9780130662712

Makkar., Dawra., \& Singh. (1991). Tannin levels in leaves of some oak species at different stages of maturity. J Sci. Food Agric 54 (4):513-519.

DOI: https://doi.org/10.1002/jsfa.27405404 $\underline{03}$

Pan, X., Chen, F., Wu, T., Tang, H. \& Zhao, Z. (2009). The Acid Bile Tolerance and Antimicrobial Property of Lactobacillus acidophilus NIT. Food Control 20: 598602.

https://doi.org/10.1016/j.foodcont.2008.08. $\underline{019}$.

Pelczar \& Chan. (2008). Dasar-Dasar Mikrobiologi Jilid I. Hadioetomo, Ratna Siri (penerjemah). 2008. Jakarta: UI Press.

Rahmawati, F. \& Bintari, S.H. (2014). Studi Aktivitas Antibakteri Sari Daun Binahong (Anredera cordifolia) terhadap Pertumbuhan Bacillus cereus Dan Salmonella enteritidis. Unnes J Life Sci 3 (2):103-111.

http://journal.unnes.ac.id/sju/index.php/Un $\underline{\text { nesJLifeSci. }}$

Rosenova, F., Haryoto. \& Suhendi, A. (2014). Uji Aktivitas Antibakteri Secara Invivo Fraksi Non Polar Ekstrak Etanol Batang Inggu (Ruta angustifolia [L.] Pers) pada Mencit 
yang Diinfeksi Staphylococcus aureus dan Streptococcus mutans. Jurnal penelitian saintek, 19(1):51-58.

https://www.researchgate.net/publication/3 $\underline{02951489}$

Rotty, L.M., Fatimawali. \& Tjitrosantoso, H. (2015). Uji Aktivitas Antibakteri Ekstrak Etanol Umbi Bawang Putih (Allium sativum L.) terhadap Bakteri Klebsiella pneumoniaeIsolat Sputum Penderita Bronkitis secara Invivo. Pharmacon 4 (3): 74-79.

https://ejournal.unsrat.ac.id/index.php/phar macon/article/view/8842.

Sarmento., Worachartcheewan., Pingaew., Prachayasittikul., Ruchirawat \& Prachayasittiku. (2015). Antimicrobial, Antioxidant And Anticancer Activities of Strychnos Lucida R. Br. Afr J Tradit Complement Altern Med,12 (4):122-127. http://dx.doi.org/10.4314/ajtcam.v12i4.18

Sepriana, C., Jekti, D.S.D. \& Zulkifli, L. (2017). Bakteri Endofit Kulit Batang Tanaman Cengkeh (Syzygium aromaticum L) dan Kemampuannya sebagai Antibakteri. Jurnal Penelitian Pendidikan IPA (JPPIPA), 3 (2): 52-59.

http://dx.doi.org/10.29303/jppipa.v3i2.92

Setiawan, O., Wahyuni, N., Susila,W.W., Rahayu, A. A. D. \& Rostiwati, T. (2014). Bidara Laut (Strychnos ligustrina Blume) Syn. S. lucida R. Br: Sumber Bahan Obat Potensial di Nusa Tenggara Barat dan Bali. Bogor: Forda Press. ISBN: 978-60214274-0-0.

Solikhah, E. N. (2016). Indonesian Medicinal Plants as Sources Secondary Metabolites for Pharmaceutical Industry. J Med Sci 48(4): 226-239.

https://doi.org/10.19106/JMedSci00480420 1606.

Sumiati, E. (2014). Uji Aktivitas Antibakteri Ekstrak Kloroform \& Ekstrak Etanol Biji Bidara Laut (Strychnos ligustrina Blume)
Terhadap Staphylococcus aureus ATCC 25923 dan Salmonella thypi. Biogenesis 2 (1):1-10. https://doi.org/10.24252/bio.v2i1.461.

Utami. (2011). Antibiotika, Resistensi dan Rasionalitas Terapi. El-Hayah 1(4): 191198.

http://dx.doi.org/10.18860/elha.v1i4.1783

Wahjoedi \& Pudjiastuti. (1993). Beberapa Informasi Efek Farmakologi Bidara Laut (Strychnos ligustrina) pada Hewan Percobaan. Warta Tumbuhan Obat Indonesia, 2(1):20-21. http://ejournal.litbang.depkes.go.id

Werdhasari. (2014). Peran Antioksidan bagi Kesehatan. Jurnal Biotek Medisiana Indonesia,3(2):59-68.

http://ejournal.litbang.depkes.go.id

Zuhrotun., Hendriani \& Kusuma, S.A.F. (2009). Pemanfaatan Ekstrak Air Bunga Rosella (Hibiscus sabdariffa L) Asal Kabupaten Bandung Barat sebagai Antiinfeksi terhadap Beberapa genus Bakteri Staphylococcus. Laporan Akhir Penelitian Peneliti Muda (Litmud). Universitas Padjadjaran. Bandung. http://pustaka.unpad.ac.id 